\title{
Review on the Surface Heat Transfer Coefficients of Radiant Systems
}

\author{
Jun Shinoda ${ }^{1, *}$, Ongun B. Kazanci ${ }^{2}$, Shin-ichi Tanabe ${ }^{1}$, and Bjarne W. Olesen ${ }^{2}$ \\ ${ }^{1}$ Department of Architecture, Waseda University, 3-4-1 Okubo, Shinjuku-ku, Tokyo 169-8555, Japan \\ ${ }^{2}$ International Centre for Indoor Environment and Energy, Department of Civil Engineering, Technical University of Denmark, Nils \\ Koppels Allé, Building 402, 2800 Kgs. Lyngby, Denmark
}

\begin{abstract}
Heat transfer coefficients are often used to describe the thermal behaviour of radiant systems and how it transfers heat between the cooled/heated surface and the room. In addition to current standards, numerous studies have been conducted to obtain the heat transfer coefficients through experiments and simulations. However, inconsistency is evident in the values or expressions suggested. Thus, this study investigated possible sources of discrepancy through an extensive literature review on articles and standards that focused on the heat transfer coefficients at the cooled/heated surface. Measurement data provided by different authors were extracted to compare both the amount of heat transfer and the actual heat transfer coefficients. Consequently, suggested values and expressions were used to predict the measurement data in other articles to examine their accuracy. Comparison of the results showed that the radiant heat transfer coefficients had a consistent value throughout the literature and had prediction error within $\pm 20 \%$. However, larger deviations and prediction errors were seen in the total and convective heat transfer. It was suggested that some of the sources of error may have been the calculation procedure of each heat transfer mechanism, choice of reference temperature and its measurement height/position, and room dimensions.
\end{abstract}

\section{Introduction}

Radiant systems are now commonly used as a comfortable and energy efficient alternative in buildings in many countries. Heat transfer of radiant systems is different from that of conventional all-air systems since cooling/heating is provided by both radiation and convection from a cooled/heated surface. In order to describe the heat transfer between the radiant surface and the room, heat transfer coefficients are often used. Heat transfer coefficients are values commonly used in calculations regarding the thermal behaviour of radiant systems, such as load calculation and dimensioning. The radiant surface serves as the boundary between the roomside and the system-side (mechanical system) and, therefore, understanding the heat transfer process at the surface is crucial for the whole design of radiant systems.

In general, radiant and convective heat transfer coefficients, or the combination of the two (total heat transfer coefficients) are used. Radiation and convection have distinct passages of heat, where the former is the heat transfer between surfaces, while the latter takes place between a surface and air (fluids). Thus, radiant heat transfer coefficients describe the heat transfer between the radiant surface and other surfaces within the room, while convective heat transfer coefficients describe the heat transfer between the radiant surface and air. The total heat transfer coefficient is used to describe

\begin{tabular}{|ll|}
\hline \multicolumn{2}{|l|}{ Nomenclature } \\
AUST & area-weighted average unheated/uncooled surface \\
$D$ & temperature $\left({ }^{\circ} \mathrm{C}\right)$ \\
$H$ & hydraulic diameter $(4 \times$ area/perimeter $)(\mathrm{m})$ \\
$h_{c}$ & height of heated $/$ cooled surface $(\mathrm{m})$ \\
$h_{r}$ & convective heat transfer coefficient $\left(\mathrm{W} / \mathrm{m}^{2} \mathrm{~K}\right)$ \\
$h_{\text {tot }}$ & radiant heat transfer coefficient $\left(\mathrm{W} / \mathrm{m}^{2} \mathrm{~K}\right)$ \\
$q_{c}$ & cotal heat transfer coefficient $\left(\mathrm{W} / \mathrm{m}^{2} \mathrm{~K}\right)$ \\
$q_{r}$ & radiant heat transfer $\left(\mathrm{W} / \mathrm{m}^{2}\right)$ \\
$q_{\text {tot }}$ & total heat transfer $\left(\mathrm{W} / \mathrm{m}^{2}\right)$ \\
$T_{a}$ & air temperature $\left({ }^{\circ} \mathrm{C}\right)$ \\
$T_{o p}$ & operative temperature $\left({ }^{\circ} \mathrm{C}\right)$ \\
$T_{\text {opl.1 }}$ & operative temperature measured at $1.1 \mathrm{~m}$ above \\
$T_{s}$ & the floor $(\mathrm{m})$ \\
$T_{w, \text { sup }}$ & surface temperature of heated $/$ cooled surface $\left({ }^{\circ} \mathrm{C}\right)$ \\
$\varepsilon$ & supply water temperature $\left({ }^{\circ} \mathrm{C}\right)$ \\
\hline
\end{tabular}

the combination of the two with a single value. Numerous investigations on the heat transfer coefficients have been carried out in previous studies, each resulting in different suggested values. Literature reviews on suggested values [1] and convective heat transfer coefficients $[2,3]$ have been conducted in the past. This study presents a preliminary literature review on the heat transfer coefficients specifically for radiant cooling and heating systems, with an emphasis on measurement conditions/setup and data. Affecting parameters for each type of heat transfer were investigated, and sources of discrepancies and considerations for further research were identified.

\footnotetext{
* Corresponding author: $\underline{\text { shinoda } @ \text { tanabe.arch.waseda.ac.jp }}$
} 
Table 1. Suggested heat transfer coefficients in standards and guidelines

\begin{tabular}{|c|c|c|c|c|}
\hline Standard/Guideline & Surface Type & $h_{t o t}\left(\mathbf{W} / \mathbf{m}^{2} \mathbf{K}\right)$ & Reference Temp. & Notes \\
\hline \multirow{5}{*}{ REHVA [4] } & Ceiling Cooling & 11 & \multirow{15}{*}{$T_{o p}$} & \multirow{15}{*}{$\begin{array}{c}h_{r} \text { assumed to be } \\
5.5 \mathrm{~W} / \mathrm{m}^{2} \mathrm{~K} \text { in } \\
\text { temperature range of } \\
15-35^{\circ} \mathrm{C}\end{array}$} \\
\hline & Ceiling Heating & 6 & & \\
\hline & Floor Cooling & 7 & & \\
\hline & Floor Heating & 11 & & \\
\hline & Wall Cooling / Heating & 8 & & \\
\hline \multirow{5}{*}{ EN1264-5 [5] } & Ceiling Cooling & 10.8 & & \\
\hline & Ceiling Heating & 6.5 & & \\
\hline & Floor Cooling & 6.5 & & \\
\hline & Floor Heating & 10.8 & & \\
\hline & Wall Cooling / Heating & 8 & & \\
\hline \multirow{5}{*}{$\begin{array}{c}\text { EN15377-1 [6] } \\
\text { ISO 11855-2 [7] }\end{array}$} & Ceiling Cooling & $8.92 \cdot\left|T_{S}-T_{o p}\right|^{0.1}$ & & \\
\hline & Ceiling Heating & 6 & & \\
\hline & Floor Cooling & 7 & & \\
\hline & Floor Heating & $8.92 \cdot\left|T_{S}-T_{o p}\right|^{0.1}$ & & \\
\hline & Wall Cooling / Heating & 8 & & \\
\hline Standard/Guideline & Surface Type & $h_{c}\left(\mathbf{W} / \mathbf{m}^{2} K\right)$ & Reference Temp. & Notes \\
\hline \multirow{8}{*}{ ASHRAE [8] } & Ceiling Cooling & $2.42 \cdot\left|T_{s}-T_{a}\right|^{0.31} / D^{0.08}$ & \multirow{8}{*}{$T_{a}$} & \multirow{4}{*}{$\begin{array}{c}\text { For large spaces where } \\
\text { room size cannot be } \\
\text { ignored }\end{array}$} \\
\hline & Ceiling Heating & $0.20 \cdot\left|T_{s}-T_{a}\right|^{0.25} / D^{0.25}$ & & \\
\hline & Floor Heating & $2.42 \cdot\left|T_{s}-T_{a}\right|^{0.31} / \mathrm{D}^{0.08}$ & & \\
\hline & Wall Cooling / Heating & $1.87 \cdot\left|T_{s}-T_{a}\right|^{0.32} / H^{0.08}$ & & \\
\hline & Ceiling Cooling & $2.13 \cdot\left|T_{s}-T_{a}\right|^{0.31}$ & & \multirow{4}{*}{$\begin{array}{c}\text { Simplified calculation } \\
\qquad \begin{array}{c}(D=4.91 \mathrm{~m}, \\
H=2.7 \mathrm{~m})\end{array}\end{array}$} \\
\hline & Ceiling Heating & $0.134 \cdot\left|T_{s}-T_{a}\right|^{0.25}$ & & \\
\hline & Floor Heating & $2.13 \cdot\left|T_{S}-T_{a}\right|^{0.31}$ & & \\
\hline & Wall Cooling / Heating & $1.78 \cdot\left|T_{s}-T_{a}\right|^{0.32}$ & & \\
\hline
\end{tabular}

\section{Suggested Heat Transfer Coefficients}

\subsection{Standards and guidelines}

The suggested total and convective heat transfer coefficients in standards are listed in Table 1. Either a fixed value or a temperature dependent expression is presented for each type of surface. For the total heat transfer coefficients, similar values are given in each standard. Similarly, though the reference temperature is not specified, REHVA [4], EN [5, 6], and ISO [7] standards all share the assumption that radiant heat transfer coefficients may be set to $5.5 \mathrm{~W} / \mathrm{m}^{2} \mathrm{~K}$ in a temperature range between $15^{\circ} \mathrm{C}$ and $35^{\circ} \mathrm{C}$.

On the other hand, ASHRAE [8] does not provide total or radiant heat transfer coefficients but suggests radiant heat transfer to be calculated based on the MRT method. In most cases, surface emissivity within a room are assumed to be equal values, resulting in a calculation between the fourth power of the cooled/heated surface temperature and AUST. In addition, ASHRAE provides expressions for the calculation of convective heat transfer. The expressions were modified to take the form of a heat transfer coefficient as shown in Table 1.

\subsection{Literature}

A total of 19 articles were reviewed, out of which 10, 5, and 5 observed the ceiling, floor, and wall, respectively. Some articles reviewed multiple surfaces. Only articles focusing on the surface heat transfer coefficients of radiant systems were chosen, excluding articles which handled inner surface heat transfer in general. Suggested values extracted from literature are shown in Table 2 . Most values were obtained through experiments, with several exceptions that performed a computational analysis [22, 26, 27].

First, the radiant heat transfer coefficients were overall in good agreement with the standards. Similar values around $5-6 \mathrm{~W} / \mathrm{m}^{2} \mathrm{~K}$ were seen for the radiant heat transfer coefficients, except for the wall systems, which had a lower value of $4.3 \mathrm{~W} / \mathrm{m}^{2} \mathrm{~K}$. While the majority used AUST as the reference temperature, Karadağ [22] used the air temperature as a reference temperature, and surrounding wall temperature as an adjusting variable.

The total and convective heat transfer coefficients had a wide range in suggested values, even for the same position and operation mode of the surface. For the total heat transfer coefficient, the reference temperatures were either air or operative temperature, the latter being more common in the cases shown here. However, Yuan et al. [19] pointed out that the same operative temperature may be found in different combinations of air temperature and mean radiant temperature (MRT), and thus included the supply water temperature in the expression to calculate the total heat transfer coefficient. This discriminates the cases with the same operative temperature but with different air temperature and MRT.

As an effect of buoyancy, the convective heat transfer varies depending on the position and temperature difference between the observed surface and fluid. Therefore, in general, ceiling cooling and floor heating has a higher convective heat transfer coefficient as compared to ceiling heating and floor cooling. Since the convective heat transfer is greatly affected by the surface (contact) area with the air, it may be enhanced by applying fins, which was the case for Zhang et al. [12]. 
Table 2. Suggested heat transfer coefficients in literature

\begin{tabular}{|c|c|c|c|c|c|c|c|c|}
\hline \multirow{2}{*}{ Author } & \multirow{2}{*}{$\begin{array}{l}\text { Surface } \\
\text { Type }^{\text {a) }}\end{array}$} & \multicolumn{3}{|c|}{ Heat Transfer Coefficient $\left(\mathbf{W} / \mathbf{m}^{2} \mathbf{K}\right)^{\text {b) }}$} & \multicolumn{3}{|c|}{ Reference Temperature } & \multirow{2}{*}{ Conditions } \\
\hline & & Tot. & Rad. & Conv. & Tot. & Rad. & Conv. & \\
\hline \multirow{4}{*}{$\begin{array}{l}\text { Okamoto et } \\
\text { al. [9] }\end{array}$} & \multirow{2}{*}{$\mathrm{CH}$} & \multirow{4}{*}{-} & 5.65 & 1.69 & \multirow{4}{*}{ - } & \multirow{4}{*}{$\mathrm{n} / \mathrm{a}$} & \multirow{4}{*}{$\mathrm{n} / \mathrm{a}$} & meandering pipes \\
\hline & & & 6.05 & 2.54 & & & & spiral pipes \\
\hline & \multirow{2}{*}{$\mathrm{CC}$} & & 5.65 & 2.54 & & & & meandering pipes \\
\hline & & & 6.05 & 1.69 & & & & spiral pipes \\
\hline $\begin{array}{c}\text { Yuan et al. } \\
{[10]}\end{array}$ & $\mathrm{CC}$ & $7.6-9.8$ & - & - & $T_{a}$ & - & - & - \\
\hline $\begin{array}{c}\text { Acikgoz } \\
\text { and Kincay } \\
\text { [11] }\end{array}$ & WC & 8.1 & 4.3 & 2.7 & $T_{a}$ & $A U S T$ & $T_{a}$ & - \\
\hline \multirow{4}{*}{$\begin{array}{l}\text { Zhang et } \\
\text { al. [12] }\end{array}$} & $\mathrm{CC}^{*}$ & 8.4 & 5.3 & 3.2 & \multirow{4}{*}{$T_{o p}$} & \multirow{4}{*}{$A U S T$} & \multirow{4}{*}{$T_{a}$} & panels with fins \\
\hline & $\mathrm{CH}^{*}$ & 6.8 & 5.7 & 1.1 & & & & *typical office room \\
\hline & $\mathrm{CC}^{* *}$ & 9.2 & 5.8 & 4.0 & & & & **high ceiling, glass \\
\hline & $\mathrm{CH}^{* *}$ & 11.8 & 5.7 & 5.9 & & & & curtain wall \& ceiling \\
\hline $\begin{array}{l}\text { Andrés- } \\
\text { Chicote et } \\
\text { al. [13] }\end{array}$ & $\mathrm{CC}$ & 8.5 & 5.4 & 4.2 & $T_{o p}$ & $A U S T$ & $T_{a}$ & - \\
\hline $\begin{array}{l}\text { Causone et } \\
\text { al. [14] }\end{array}$ & $\begin{array}{l}\mathrm{CC} \\
\mathrm{CH}\end{array}$ & $\begin{array}{c}13.2 \\
5.8\end{array}$ & $\begin{array}{l}5.6 \\
5.6\end{array}$ & $\begin{array}{l}4.4 \\
0.3\end{array}$ & $T_{o p}$ & $A U S T$ & $T_{a}$ & - \\
\hline \multirow{2}{*}{$\begin{array}{l}\text { Cholewa et } \\
\text { al. [15] }\end{array}$} & $\mathrm{CH}$ & 5.6 & 5.5 & 0.0 & \multirow[b]{2}{*}{$T_{o p}$} & \multirow{2}{*}{ AUST } & \multirow[b]{2}{*}{$T_{a}$} & \\
\hline & $\mathrm{CC}$ & $9.36\left(\mathrm{~T}_{\text {opl.1. }}-\mathrm{T}_{\mathrm{s}}\right)^{0.1}$ & 5.2 & $2.04-3.65 *$ & & & & {$[18]$ by $22 \%$} \\
\hline Cholewa et & FH & $7.67\left(\mathrm{~T}_{\mathrm{s}}-\mathrm{T}_{\mathrm{op} 1.1}\right)^{0.1}$ & 5.6 & $2.2-3.5 *$ & & & & *decrease value from \\
\hline al. [16] & $\mathrm{FC}$ & 5.7 & 5.0 & 0.1 & $I_{o p}$ & AUST & $I_{a}$ & [18] by $24 \%$ \\
\hline Koca and & WH & 8.57 & 5.74 & 2.44 & $T$ & AUST & $T$ & 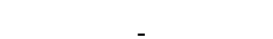 \\
\hline Çetin [17] & $\mathrm{CH}$ & 7.28 & 5.7 & 0.82 & $I_{o p}$ & $A \cup D I$ & $I_{a}$ & - \\
\hline & & $8.46-8.94$ & $5.38-5.57$ & $3.07-3.22$ & & & & wall 1 \\
\hline Koca et al. & WH & $8.16-8.48$ & $5.38-5.57$ & $2.25-2.40$ & $T_{o p}$ & AUST & $T_{a}$ & wall 2 \\
\hline & & $8.76-9.28$ & $5.98-6.25$ & $2.59-2.73$ & & & & wall $1+2$ \\
\hline & $\mathrm{CC}$ & $7.49 \mid T_{s}-T_{w, s u p \mid}-0^{-0.032}$ & & & & & & \\
\hline $\begin{array}{l}\text { Yuan et al. } \\
\text { [19] }\end{array}$ & & $\begin{array}{c}\left|T_{o p}-T_{s}\right|^{0.09} \\
6.684\left|T_{s}-T_{w}\right|-0.139\end{array}$ & - & - & $T_{o p}$ & - & - & - \\
\hline & $\mathrm{CH}$ & $\begin{array}{r}0.084\left|I_{s}-I_{w, s u p}\right| \\
\left|T_{o p}-T_{s}\right|^{0.09} \\
\end{array}$ & & & & & & \\
\hline & & & & 3.0 & & & & panel front-side \\
\hline Miriel et al. & Cl & - & & 0.8 & & & $T$ & panel backside \\
\hline [20] & $\mathrm{CH}$ & 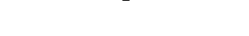 & 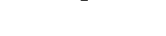 & 1.25 & 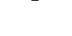 & 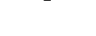 & $I_{a}$ & panel front-side \\
\hline & & & & 1.75 & & & & panel backside \\
\hline & WH & & & $\left(1.823 / D^{0.121}\right)\left(T_{a}-T_{s}\right)^{0.293}$ & & & & \\
\hline $\begin{array}{l}\text { Awbi and } \\
\text { Hatton }\end{array}$ & FH & - & - & $\left(2.175 / D^{0.076}\right)\left(T_{a}-T_{s}\right)^{0.308}$ & - & - & $T_{a}$ & - \\
\hline & $\mathrm{CH}$ & & & $\left(0.704 / D^{0.601}\right)\left(T_{a}-T_{s}\right)^{0.133}$ & & & & \\
\hline $\begin{array}{c}\text { Karadağ } \\
{[22]}\end{array}$ & $\mathrm{CC}$ & $11.5 \varepsilon\left(T_{a}-T_{s}\right)^{0.09}$ & - & $3.1\left(T_{a}-T_{s}\right)^{0.22}$ & $T_{a}$ & - & $T_{a}$ & - \\
\hline $\begin{array}{l}\text { Olesen et } \\
\text { al. [23] }\end{array}$ & $\mathrm{FC}$ & 7.5 & 5.5 & 1.0 & $T_{o p}$ & $A U S T$ & $T_{a}$ & - \\
\hline $\begin{array}{l}\text { Evren et al. } \\
\text { [24] }\end{array}$ & FH & $9.9^{*}, 10.1 * *$ & 5.4 & 3.7 & $T_{o p}$ & $A U S T$ & $T_{a}$ & $\begin{array}{l}\text { Based on: } \\
* \text { calculated } q_{t o t} \\
* * \text { measured } q_{t o t}\end{array}$ \\
\hline Khalifa [3] & $\begin{array}{l}\mathrm{FH} \\
\mathrm{CH}\end{array}$ & - & - & $\begin{array}{c}2.416\left(T_{a}-T_{s}\right)^{0.31} / D^{0.076} \\
0.203\left(T_{a}-T_{s}\right)^{0.25} / D^{0.24}\end{array}$ & - & - & $T_{a}$ & $\begin{array}{l}\text { Quoted from Min et al. } \\
{[25]}\end{array}$ \\
\hline $\begin{array}{c}\text { Karadağ } \\
{[26]}\end{array}$ & $\mathrm{CC}$ & - & $8 \varepsilon\left(T_{a}-T_{s}\right)^{m}$ & $2.6\left(T_{a}-T_{s}\right)^{0.27}$ & - & $T_{a}$ & $T_{a}$ & $\begin{array}{l}-0.06<\mathrm{m}<-0.1 \\
(\text { wall temp. dependent) }\end{array}$ \\
\hline $\begin{array}{c}\text { Acikgoz } \\
{[27]}\end{array}$ & WH & $\begin{array}{c}10 \varepsilon^{0.80}\left(T_{s}-T_{a}\right)^{0.07} \\
10.50\end{array}$ & $\begin{array}{c}- \\
5.50\end{array}$ & $\begin{array}{c}1.5(\mathrm{H} / \mathrm{L})^{0.09}\left(T_{a}-T_{s}\right)^{0.47} \\
3.50\end{array}$ & $T_{a}$ & $\begin{array}{c}- \\
A U S T \\
\end{array}$ & $T_{a}$ & - \\
\hline
\end{tabular}

a) CC: ceiling cooling, $\mathrm{CH}$ : ceiling heating, FC: floor cooling, FH: floor heating, WC: wall cooling, WH: wall heating

b) Tot.: total, Rad.: radiant, Conv.: convective

Fig. 1. shows the measured heat flux and heat transfer coefficient of the measurements in literature. Results of ceiling cooling cases are shown, since it had the most number of measurement cases, and the convective portion is larger compared to the ceiling heating or floor cooling cases. The $\Delta T$ represents the temperature difference between the cooled surface and the reference temperature specified in each article.

Results show that the radiant heat transfer had a highly linear correlation with $\Delta T$, resulting in a consistent radiant heat transfer coefficient throughout the literature. The plots largely deviating from the other plots are cases with aluminum foil on the cooled surface, having a lower emissivity of 0.1 . The same deviation can be seen in the total heat transfer coefficient as well. Overall, the total heat transfer coefficients showed a constant value between $8-10 \mathrm{~W} / \mathrm{m}^{2} \mathrm{~K}$, except for the cases of Causone et al. [14], which had a value between $12-14 \mathrm{~W} / \mathrm{m}^{2} \mathrm{~K}$. The convective heat transfer coefficients, on the other hand, had larger differences within and between articles, ranging from $2-6 \mathrm{~W} / \mathrm{m}^{2} \mathrm{~K}$. Results from Cholewa et al. [15] had the largest deviation within the measurements, due to the use of multiple reference temperatures for the same measurements. Calculation within a small band of $\Delta T$ may have had an effect as well. On the contrary, measurements by Yuan et al. [19] had a stable value of $3-4 \mathrm{~W} / \mathrm{m}^{2} \mathrm{~K}$ within a large band of $\Delta T$ between 3-12 K. 


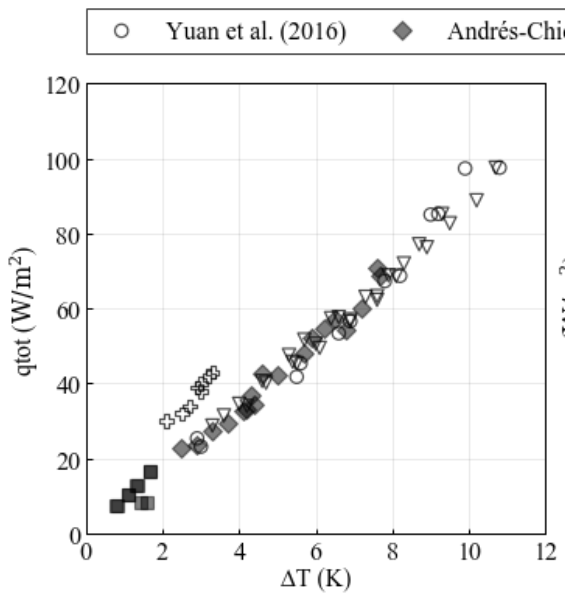

(a) Total Heat Transfer

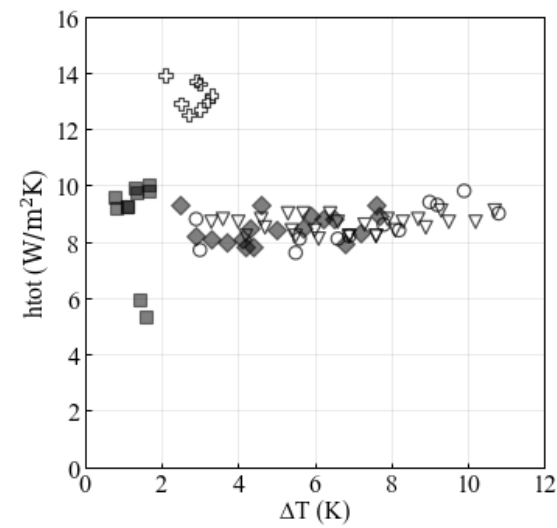

(d) Total Heat Transfer Coefficient

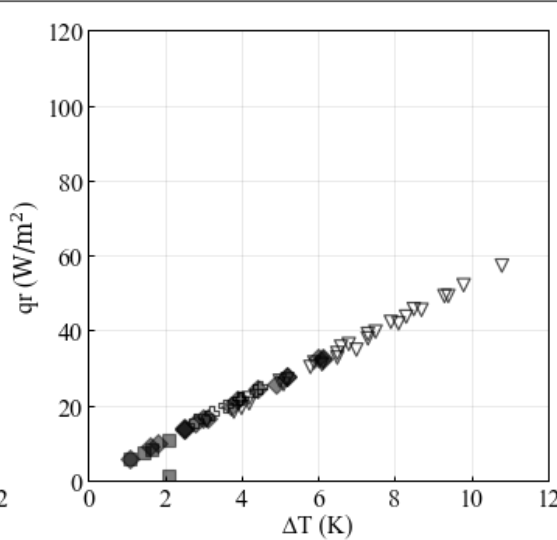

(b) Radiant Heat Transfer

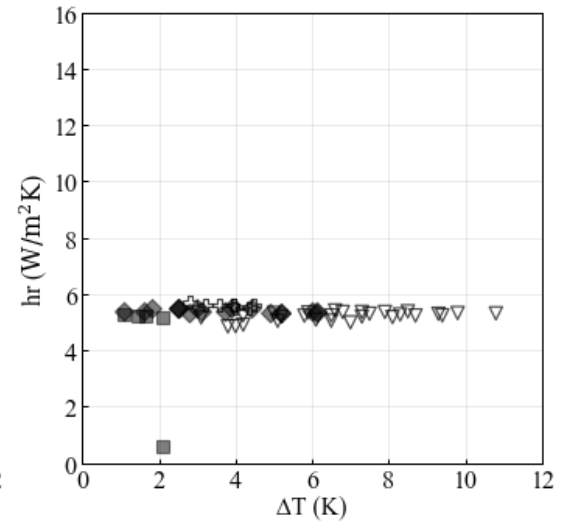

(e) Radiant Heat Transfer Coefficient \begin{tabular}{lll} 
Cholewa et al. (2017) & $\nabla$ & Yuan et al. (2017) \\
\hline
\end{tabular}

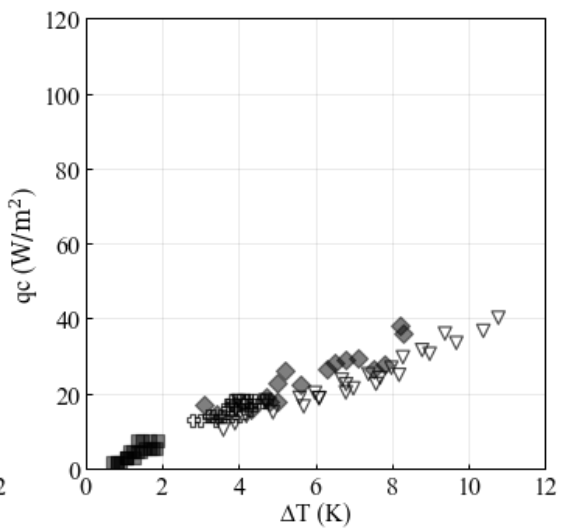

(c) Convective Heat Transfer

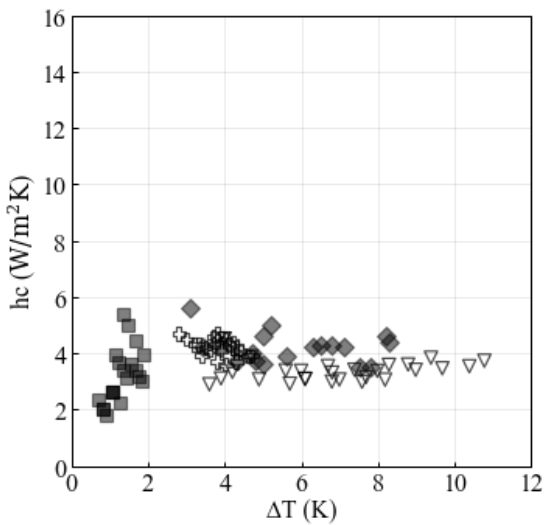

(f) Convective Heat Transfer Coefficient

Fig. 1. Measured heat fluxes and heat transfer coefficients in literature (ceiling cooling cases)
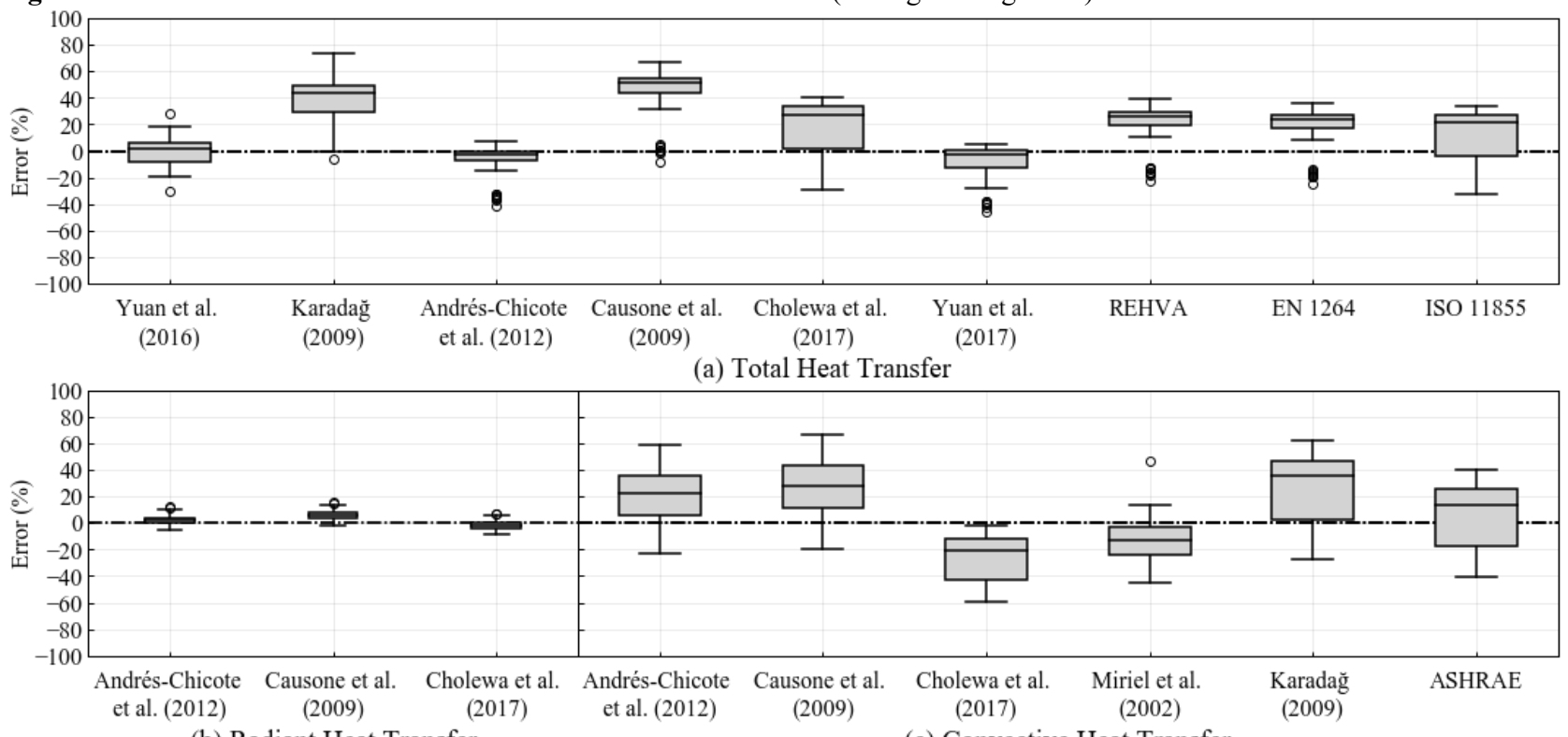

(b) Radiant Heat Transfer

(c) Convective Heat Transfer

Fig. 2. Prediction accuracy of heat transfer coefficients suggested in literature

\section{Prediction Accuracy}

The purpose of heat transfer coefficients is to predict the amount of heat transfer in a given condition. However, as stated in the previous section, the suggested values and expressions differ for each standard/study. Thus, each was used to predict the amount of heat transfer of the ceiling cooling cases to compare with every measurement data plotted in Fig. 1 (excluding the $\varepsilon=0.1$ cases). The distribution of the percentage of error for each prediction source is shown in Fig. 2. The whiskers represent the furthest data within 1.5 interquartile ranges from the first and third quartiles, and any data out of range is plotted as circles. Positive and negative errors each represent overprediction and underprediction. 
Table 3. Measurement and Calculation Conditions for each Article

\begin{tabular}{|c|c|c|c|c|c|c|c|c|}
\hline \multirow{2}{*}{ Author } & \multirow{2}{*}{$\begin{array}{c}\text { Dimensions } \\
1 \times \mathrm{w} \times \mathrm{h}(\mathrm{m}) \\
\end{array}$} & \multirow{2}{*}{$\begin{array}{l}\text { Radiant Surface } \\
\text { Area }\left(\mathrm{m}^{2}\right)\end{array}$} & \multicolumn{3}{|c|}{ Heat Flux Measurement/Calculation Method } & \multicolumn{2}{|c|}{ Meas. Height (m) } & \multirow{2}{*}{$\begin{array}{l}\text { Ventilation/ } \\
\text { Air Supply }\end{array}$} \\
\hline & & & Tot. & Rad. & Conv. & $T_{o p}$ & $T_{a}$ & \\
\hline $\begin{array}{l}\text { Okamoto et } \\
\text { al. [9] }\end{array}$ & $\mathrm{n} / \mathrm{a}$ & $\mathrm{n} / \mathrm{a}$ & $\begin{array}{l}\text { measured from } \\
\text { surface }\end{array}$ & $\begin{array}{l}\text { measured } \\
\text { from surface }\end{array}$ & total - radiant & $\mathrm{n} / \mathrm{a}$ & $\mathrm{n} / \mathrm{a}$ & $\mathrm{n} / \mathrm{a}$ \\
\hline $\begin{array}{c}\text { Yuan et al. } \\
{[10]}\end{array}$ & $4.2 \times 3.6 \times 2.4$ & 12 & system - heat loss & (20) & - & - & $\mathrm{n} / \mathrm{a}$ & no \\
\hline $\begin{array}{l}\text { Acikgoz and } \\
\text { Kincay [11] }\end{array}$ & $\begin{array}{c}1.8 \times 1.8 \times \\
2.85\end{array}$ & 5.13 & system & calculation & total - radiant & - & 1.45 & $\mathrm{n} / \mathrm{a}$ \\
\hline $\begin{array}{c}\text { Zhang et al. } \\
\text { [12] }\end{array}$ & $\begin{array}{l}12 \times 6 \times 3 \\
10.5 \times 6 \times 5\end{array}$ & $\begin{array}{c}26 / 72.8 \\
19.5 / 54.6 \\
\text { (projected / } \\
\text { surface) }\end{array}$ & system & calculation & total - radiant & 1.5 & 1.5 & $\mathrm{n} / \mathrm{a}$ \\
\hline $\begin{array}{l}\text { Andrés- } \\
\text { Chicote et } \\
\text { al. [13] }\end{array}$ & $3.6 \times 3.6 \times 3$ & 4.79 & system & calculation & total - radiant & $\mathrm{n} / \mathrm{a}$ & $\mathrm{n} / \mathrm{a}$ & yes \\
\hline $\begin{array}{l}\text { Causone et } \\
\text { al. [14] }\end{array}$ & $\begin{array}{c}4.3 \times 2.7 \times \\
2.56\end{array}$ & 11.61 & system - heat loss & calculation & total - radiant & 1.1 & $\begin{array}{l}0.1,1.1 \\
\quad 1.7\end{array}$ & $\mathrm{n} / \mathrm{a}$ \\
\hline $\begin{array}{l}\text { Cholewa et } \\
\text { al. }[15,16]\end{array}$ & $\begin{array}{c}1.56 \times 1.56 \times \\
2.21\end{array}$ & 2.43 & $\begin{array}{l}\text { measured from } \\
\text { surface }\end{array}$ & calculation & total - radiant & $\begin{array}{l}0.6, \\
1.1\end{array}$ & $\begin{array}{l}0.1,0.6 \\
1.1,1.7\end{array}$ & $\mathrm{n} / \mathrm{a}$ \\
\hline $\begin{array}{l}\text { Koca and } \\
\text { Çetin [17] }\end{array}$ & $4 \times 4 \times 3$ & 6,14 & system - heat loss & calculation & total - radiant & $\mathrm{n} / \mathrm{a}$ & $\mathrm{n} / \mathrm{a}$ & no \\
\hline $\begin{array}{c}\text { Koca et al. } \\
\text { [18] }\end{array}$ & $6 \times 4 \times 3$ & $4.4,11,15.4$ & system - heat loss & calculation & total - radiant & 1.1 & 1.1 & $\mathrm{n} / \mathrm{a}$ \\
\hline $\begin{array}{c}\text { Yuan et al. } \\
\text { [19] }\end{array}$ & $4.2 \times 3.6 \times 2.4$ & 12 & system - heat loss & calculation & 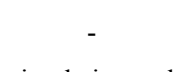 & $\mathrm{n} / \mathrm{a}$ & $\mathrm{n} / \mathrm{a}$ & no \\
\hline $\begin{array}{l}\text { Miriel et al. } \\
\quad[20]\end{array}$ & $\mathrm{n} / \mathrm{a}$ & 14 & - & - & $\begin{array}{l}\text { simulation and } \\
\text { measurement } \\
\text { comparison }\end{array}$ & - & $\mathrm{n} / \mathrm{a}$ & $\mathrm{n} / \mathrm{a}$ \\
\hline $\begin{array}{l}\text { Awbi and } \\
\text { Hatton [21] }\end{array}$ & $\begin{array}{c}2.78 \times 2.78 \times \\
2.3\end{array}$ & 5.928 & system - heat loss & calculation & total - radiant & - & 1.15 & $\mathrm{n} / \mathrm{a}$ \\
\hline $\begin{array}{l}\text { Olesen et al. } \\
{[23]}\end{array}$ & $6 \times 4 \times 2.8$ & 24 & system - heat loss & calculation & total - radiant & $\begin{array}{l}0.6, \\
1.1\end{array}$ & $0.6,1.1$ & $\mathrm{n} / \mathrm{a}$ \\
\hline $\begin{array}{c}\text { Evren et al. } \\
{[24]}\end{array}$ & $\begin{array}{c}2.74 \times 2.25 \times \\
2.45 \\
\end{array}$ & 6.165 & $\begin{array}{c}\text { radiant }+ \\
\text { convective }\end{array}$ & calculation & calculation & $\mathrm{n} / \mathrm{a}$ & $\mathrm{n} / \mathrm{a}$ & $\mathrm{n} / \mathrm{a}$ \\
\hline
\end{tabular}

First, the radiant heat transfer had the highest accuracy for all the suggested values. In all cases, the prediction percentage of error was within $\pm 20 \%$. However, larger distributions of error were seen in the total and convective heat transfer. Regardless of the use of constant values or temperature (and other parameter) dependent expressions, each resulted in a large deviation of $60-80 \%$ in its prediction. Furthermore, most suggested values gathered on the positive side of the error, meaning that the value was overpredicted. For the total heat transfer coefficient, the values proposed by AndrésChicote et al. [13] and Yuan et al. [19] were able to keep the predicted values equal to or less than the measured values. For the convective heat transfer, the equation proposed by Cholewa et al. [15] had all the errors on the negative side, which correspond to their argument that most convective heat transfer in literature are over evaluated.

\section{Sources of Error}

\subsection{Calculation Method of Heat Transfer}

Table 3 lists the measurement and calculation conditions for each researcher that performed experiments. In most of the cases, radiant heat transfer is obtained through numerical calculation using surface emissivity and temperature of each surface within the room. Thus, the obtained value showed similar results for each article. The total heat transfer is obtained either by calculation using inlet and outlet water temperatures and flow rate of the radiant system or measuring the emission from the

surface using equipment such as heat flux sensors. In the articles reviewed in this study, the former approach was more commonly taken. However, Cholewa et al. $[15,16]$ argues that the latter approach should be taken, since calculations based on the radiant system input and outputs do not necessarily represent the heat flux towards the room, due to the heat loss towards the other side of the cooled/heated surface. Some articles indicate that heat loss was taken into account, however the calculation method of heat loss was not specified in most cases. Measuring the total emission from the surface, on the other hand, has its own drawbacks. When measuring the heat flux from a surface, it must be noted that the measured value only represents the heat transfer at the point it is placed. Hence, the validity of the measured value to represent the total heat transfer must be considered. Furthermore, contact sensors such as heat flux sensors or surface temperature sensors change the surface conditions and temperature of the measurement point it is placed, which is another possible source of error.

In addition, almost all the articles with an experimental approach obtained the convective heat transfer from the difference between the total and radiant heat transfer. As previously stated, radiant heat transfer had little deviation between each study, therefore the errors in the total heat transfer will likely appear in the convective heat transfer. Furthermore, since the convective heat transfer has smaller values compared to the total heat transfer, the deviation will be relatively larger when converted to heat transfer coefficients.

It must be noted that since a source of error lies within the calculation process to obtain the total and 
convective heat transfer, the prediction accuracy shown in Fig. 2. does not necessarily represent the effectiveness of each value/expression. Instead, it shows that the obtained heat transfer and/or heat transfer coefficients may not be on equal grounds to compare the validity of each other's measurements. Either a re-examination of the calculation process or the use of other parameters, or both, may be necessary.

\subsection{Reference Temperature}

The selection of reference temperature is one of the determining factors of heat transfer coefficients. Olesen et al. [23] performed multiple calculations using the same amount of convective and total heat transfer with different reference temperatures to demonstrate the effect of its choice for floor cooling conditions. It was suggested that the reference temperature should be used according to the purpose of the heat transfer coefficients; for instance, when comparing with comfort conditions, the operative temperature at 0.6 and $1.1 \mathrm{~m}$ above the floor should each be used for a sedentary and standing person, respectively. Subsequent studies also compared heat transfer coefficients based on the reference temperature measurement height for convective and total heat transfer and resulted in different heat transfer coefficients for each height [14-16].

\subsection{Temperature Stratification and Ventilation}

As previously stated, the choice of reference temperature and its measurement height altered the outcome of the total and convective heat transfer coefficients. In other words, there was a temperature stratification during the measurements. Yuan et al. [10, 19] clearly stated that no ventilation or air supply was used, in order to minimize forced convection on the cooled/heated surface. On the other hand, Andrés-Chicote et al. [13] supplied air to their test chamber to obtain a uniform environment, taking necessary precautions to keep the air velocity within the room at a low value and avoiding forced convection on the cooled/heated surface. Other articles observed in the present review did not specify whether or not such systems were used.

Applying air movements within the test chamber will greatly affect the indoor environment in terms of temperature stratification and air velocity. Hence, the impact of the reference temperature measurement height will be affected as well. Moreover, as previous studies [28] have indicated, increased air velocity will result in a higher heating/cooling capacity of the radiant system by the effect of forced convection. There is most likely a trade-off between temperature uniformity and air velocity in this case. However, different ventilation strategies should be compared for a closer real-life condition. The values presented in this paper are intended for natural convection, thus additional parameters such as air change rate should be considered if the heat transfer falls into a mixed or forced convection regime.

\subsection{Dimensions}

The suggested correlations for the convective heat transfer in Tables 1,2 show that in addition to the temperature difference, the hydraulic diameter or wall height (i.e. dimensions of the room and cooled/ heated surface) are included. As listed in Table 3, the dimensions of each test chamber and the surface area of the controlled surface was different, resulting in inconsistencies. The calculated hydraulic diameters ranged between 1.6-3.4 m. Out of the measurement cases plotted in Fig. 1, the lowest and highest values were seen in the test chambers of Cholewa et al. [15] and Yuan et al. [10], respectively. In the detailed calculation suggested by ASHRAE [8], the differences in the hydraulic diameters resulted in an error of about $1 \mathrm{~W} / \mathrm{m}^{2} \mathrm{~K}$ at $\Delta T=8$ $\mathrm{K}$ in the resulting convective heat transfer coefficient. A smaller hydraulic diameter will result in a larger temperature dependency, and a more stable convective heat transfer coefficient with a larger hydraulic diameter. This relationship was observed in the two articles, as previously stated $[10,15]$.

\section{Conclusion}

A preliminary review was conducted on the heat transfer coefficients of radiant systems. Suggested values/expressions and measurement results from standards, guidelines and published articles were comprehensively collected and analyzed. In the literature, multiple studies were conducted to measure the total, radiant, and convective heat transfer, and heat transfer coefficients. Measurement conditions and calculation methods varied for each study, resulting in a wide range of suggested values.

Due to the well-defined, shared calculation method, small deviations were seen throughout the literature for the radiant heat transfer and heat transfer coefficient. However, a larger deviation was observed for both within and between each measurement for the total and convective heat transfer. The total heat transfer may be calculated by the water circuit or measured directly by heat flux sensors, each requiring careful consideration of heat loss and temperature representation of the surface. Convective heat transfer is calculated by the difference between the total and radiant heat transfer, accumulating possible errors on the convective heat transfer and consequently the convective heat transfer coefficient. The impact of such errors on the system should be further analyzed through simulations.

In addition, room and cooled/heated surface dimensions and the use of air supply are likely to alter the outcomes of the convective heat transfer, since they affect the temperature distribution within the room. Temperature stratification will occur regardless of air supply, thus making the measurement height of the reference temperature critical. This applies to the total heat transfer as well, in addition to the choice of reference temperature (air or operative). When air is supplied to the room, mixed or forced convection may also take place, resulting in even more parameters that 
can affect the heat transfer such as air velocity, which needs to be considered when assuming real life conditions. Hence, each of the mentioned parameters should be observed and specified in further studies.

\section{References}

1. K.-N. Rhee and K.W. Kim, A 50 year review of basic and applied research in radiant heating and cooling systems for the built environment. Build Environ, 91, 166-190 (2015)

2. A.-J. N. Khalifa, Natural convective heat transfer coefficient - a review I. Isolated vertical and horizontal surfaces. Energy Convers Manag, 42, 491-504 (2001)

3. A.-J. N. Khalifa, Natural convective heat transfer coefficient - a review: II. Surfaces in two- and three-dimensional enclosures. Energy Convers Manag, 42(4), 505-517 (2001)

4. J. Babiak, B.W. Olesen, D. Petras, Low temperature heating and high temperature cooling, REHVA Guidebook no. 7. (2009)

5. EN1264-5 Water based surface embedded heating and cooling systems - Part 5: Heating and cooling surfaces embedded in floors, ceilings and walls Determination of the thermal output, CEN (2008)

6. EN15377-1 Heating systems in buildings - Design of embedded water based surface heating and cooling systems - Part 1: Determination of the design heating and cooling capacity, CEN (2008)

7. ISO11855-2 Building environment design - Design, dimensioning, installation and control of embedded radiant heating and cooling systems - Part 2: Determination of the design heating and cooling capacity, International Organization for Standardization (2012)

8. ASHRAE, ASHRAE Handbook - HVAC Systems and Equipment, (2012)

9. S. Okamoto, H. Kitora, H. Yamaguchi, T. Oka, A simplified calculation method for estimating heat flux from ceiling radiant panels. Energy Build, 42(1), 29-33 (2010)

10. Y. Yuan, X. Zhang, X. Zhou, J. Gao, An experiment-oriented simulation method for cooling capacity determination of cooling ceiling radiant panel system. Sci Technol Built Environ, 22(6), 831-844 (2016)

11. O. Acikgoz, O. Kincay, Experimental and numerical investigation of the correlation between radiative and convective heat-transfer coefficients at the cooled wall of a real-sized room. Energy Build, 108, 257-266 (2015)

12. L. Zhang, X.-H. Liu, Y. Jiang, Experimental evaluation of a suspended metal ceiling radiant panel with inclined fins. Energy Build, 62, 522-529. (2013)

13. M. Andrés-Chicote, A. Tejero-González, E. Velasco-Gómez, F. J. Rey-Martínez, Experimental study on the cooling capacity of a radiant cooled ceiling system. Energy Build, 54, 207-214 (2012)
14. F. Causone, S. P. Corgnati, M. Filippi, B.W. Olesen, Experimental evaluation of heat transfer coefficients between radiant ceiling and room. Energy Build, 41(6), 622-628 (2009)

15. T. Cholewa, R. Anasiewicz, A. Siuta-Olcha, M. A. Skwarczynski, On the heat transfer coefficients between heated/cooled radiant ceiling and room. Appl Therm Eng, 117, 76-84 (2017)

16. T. Cholewa, M. Rosiński, Z. Spik, M. R. Dudzińska, A. Siuta-Olcha, On the heat transfer coefficients between heated/cooled radiant floor and room. Energy Build, 66, 599-606 (2013)

17. A. Koca, G. Çetin, Experimental investigation on the heat transfer coefficients of radiant heating systems: Wall, ceiling and wall-ceiling integration. Energy Build, 148, 311-326 (2017)

18. A. Koca, Z. Gemici, Y. Topacoglu, G. Cetin, R. C. Acet, B. B. Kanbur, Experimental investigation of heat transfer coefficients between hydronic radiant heated wall and room. Energy and Buildings, 82, 211-221 (2014)

19. Y. Yuan, X. Zhang, X. Zhou, Simplified correlations for heat transfer coefficient and heat flux density of radiant ceiling panels. Sci Technol Built Environ, 23(2), 251-263 (2017)

20. J. Miriel, L. Serres, A. Trombe, Radiant ceiling panel heating-cooling systems: experimental and simulated study of the performances, thermal comfort and energy consumptions. Appl Therm Eng, 22(16), 1861-1873 (2002)

21. H. B. Awbi, A. Hatton, Natural convection from heated room surfaces. Energy and Buildings, 30(3), 233-244 (1999)

22. R. Karadağ, New approach relevant to total heat transfer coefficient including the effect of radiation and convection at the ceiling in a cooled ceiling room. Appl Therm Eng, 29(8), 1561-1565 (2009)

23. B. W. Olesen, E. Michel, F. Bonnefoi, M. De Carli, Heat exchange coefficient between floor surface and space by floor cooling - theory or a question of definition, ASHRAE Trans, 106, 684-694 (2000).

24. M. F. Evren, A. Özsunar, A. Biyikoglu, B. Kilkis, Determination of heat transfer coefficient between heated floor and space using the principles of ANSI/ASHRAE standard 138 test chamber, ASHRAE Tans, 123, 71-81 (2017)

25. T. C. Min, L. F. Schutrum, G. V. Parmelee, J. D. Vouris, Natural convection and radiation in a panel heated room, ASHRAE Trans, 62, 337-358 (1956)

26. R. Karadağ, The investigation of relation between radiative and convective heat transfer coefficients at the ceiling in a cooled ceiling room. Energy Convers Manag, 50(1), 1-5 (2009)

27. O. Acikgoz, A novel evaluation regarding the influence of surface emissivity on radiative and total heat transfer coefficients in radiant heating systems by means of theoretical and numerical methods. Energy Build, 102, 105-116 (2015)

28. J.-W. Jeong, S. A. Mumma, Ceiling radiant cooling panel capacity enhanced by mixed convection in mechanically ventilated spaces. Appl Therm Eng, 23, 2293-2306 (2003) 